\title{
Identification of horse chestnut coat color genotype using SNaPshot ${ }^{\circledR}$
}

\author{
Fernando Rendo ${ }^{\dagger}$, Mikel Iriondo ${ }^{\dagger}$, Carmen Manzano ${ }^{\dagger}$ and Andone Estonba*†
}

\author{
Address: Department of Genetics, Physical Anthropology and Animal Physiology, Faculty of Science and Technology, University of the Basque \\ Country, E-48940 Bilbao, Spain \\ Email: Fernando Rendo - fernando.rendo@ehu.es; Mikel Iriondo - m.iriondo@ehu.es; Carmen Manzano - carmen.manzano@ehu.es; \\ Andone Estonba* - andone.estonba@ehu.es \\ * Corresponding author †Equal contributors
}

Published: 16 December 2009

BMC Research Notes 2009, 2:255 doi:10.1 186/1756-0500-2-255

This article is available from: http://www.biomedcentral.com/1756-0500/2/255

(C) 2009 Estonba et al; licensee BioMed Central Ltd.

This is an Open Access article distributed under the terms of the Creative Commons Attribution License (http://creativecommons.org/licenses/by/2.0), which permits unrestricted use, distribution, and reproduction in any medium, provided the original work is properly cited.
Received: 30 September 2009

Accepted: 16 December 2009

\begin{abstract}
Background: The Cantabrian Coast horse breeds of the lberian Peninsula have mainly black or bay colored coats, but alleles responsible for a chestnut coat color run in these breeds and occasionally, chestnut horses are born. Chestnut coat color is caused by two recessive alleles, e and $\mathrm{e}^{a}$, of the melanocortin-I receptor gene, whereas the presence of the dominant, wild-type $E$ allele produces black or bay coat horses. Because black or bay colored coats are considered as the purebred phenotype for most of the breeds from this region, it is important to have a fast and reliable method to detect alleles causing chestnut coat color in horses.
\end{abstract}

Findings: In order to assess coat color genotype in reproductive animals with a view to avoiding those bearing chestnut alleles, we have developed a reliable, fast and cost-effective screening device which involves Single Nucleotide Polymorphism (SNP) detection based on SNaPshot ${ }^{\circledR}$ (Applied Biosystems) methodology. We have applied this method to four native breeds from the lberian Cantabrian Coast: Pottoka and Jaca Navarra pony breeds, in which only black or bay coats are acceptable, and Euskal Herriko Mendiko Zaldia and Burguete heavy breeds, in which chestnut coats are acceptable. The frequency of the chestnut alleles ranged between $f=0.156-0.322$ in pony breeds and between $f=0.604-0.716$ in heavy breeds.

Conclusions: This study demonstrates the usefulness of the DNA methodology reported herein as a device for identifying chestnut alleles; the methodology constitutes a valuable tool for breeders to decrease the incidence of chestnut animals among Cantabrian Coast pony breeds.

\section{Findings}

Local horse breeds in the Cantabrian Coast of the Iberian Peninsula include the Pottoka, Jaca Navarra, Losino, Monchino, Asturcón, Galego and Garrano ponies, and the Euskal Herriko Mendiko Zaldia (EHMZ) and Burguete heavy breeds. With a view to preserving these breeds, purebred standards have recently been defined. For the pony breeds, black and bay colors are considered to be the original coat colors $[1,2]$, even though chestnut individuals do exist, while both bay and chestnut coats are the typical coat colors in the EHMZ and Burguete breeds. The absence of chestnut horses in the Iberian Peninsula until the Medieval Age [3], together with the naturally occurring isolation of these breeds, suggest that introgression of chestnut alleles most likely occurred around the 1930s when local mares were crossed with stallions of Breton, 
Percheron and Ardennais breeds, which are mainly chestnut, to improve the capacity for agricultural work and meat production [4]. For this reason, chestnut coat color individuals are not allowed to be included in the official stud book in the Cantabrian Coast pony breeds. In order to facilitate the selection and enrichment of the purebred populations of these horses, in terms of coat color, we propose a method to assess the coat color genotype among reproductive animals, since chestnut color is known to be a genetically recessive trait.

Chestnut coat color is controlled by the Extension gene [5], which encodes the melanocortin-1 receptor $(M C 1 R)$. In horses, three alleles responsible for the major coat phenotypes have been identified in the MC1R exon 1. Marklund et al. [6] identified a chestnut $e$ allele resulting from a single missense mutation at position C901T (S83F). Later, Wagner and Reissmann [7] identified a second chestnut
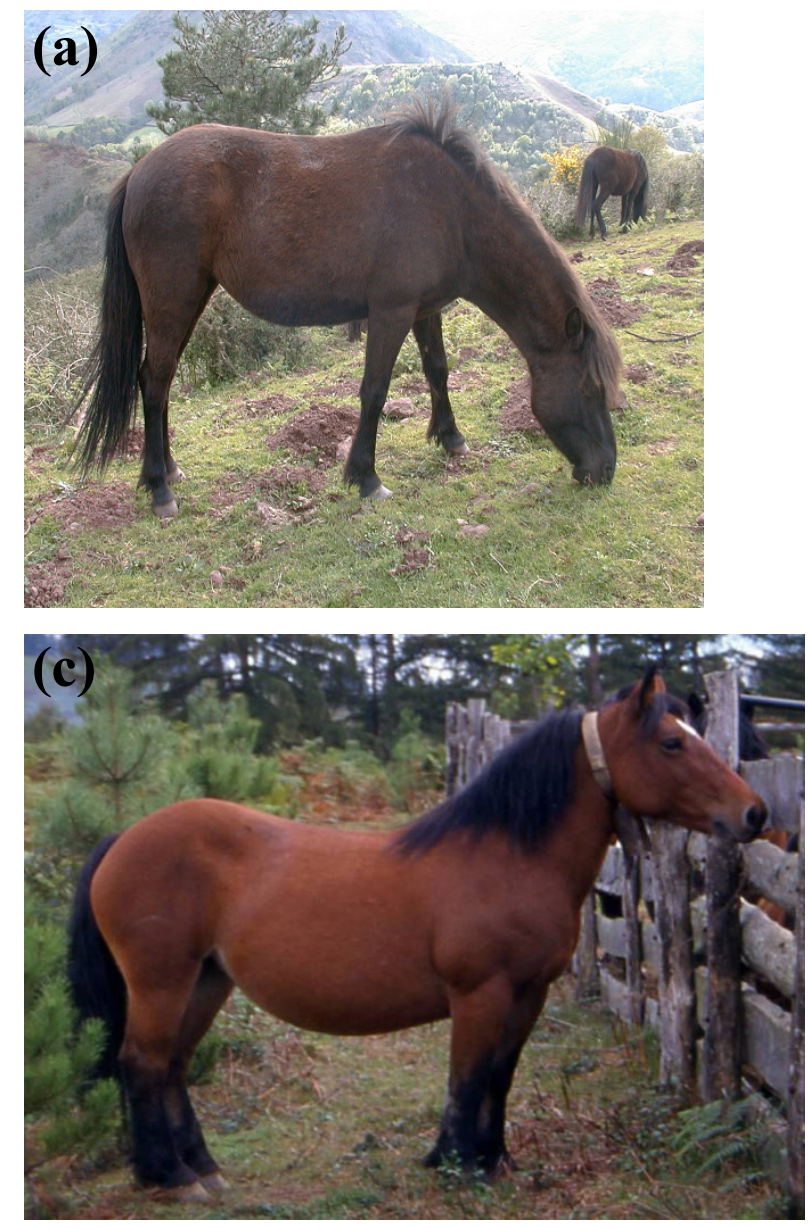

allele $e^{a}$, resulting from another single missense mutation at position G903A (D84N). The wild-type allele $E$ is dominant at the MC1R locus, and its presence produces a black or bay coat, whereas the recessive $e$ and $e^{a}$ alleles give rise to a chestnut coat when they are present in a homozygous or heterozygous configuration [7].

The design of a simple method for the quick identification of mutations responsible for chestnut coat color is of interest to many horses breeders. This identification is usually performed using the Polymerase Chain Reaction based on Restriction Fragment Length Polymorphisms (PCR-RFLP) [6], which is a time-consuming technique involving a high level of manipulation. Also an RT-PCR based method has recently been proposed [8]. These two methodologies are not a cost-effective techniques when additional single nucleotide polymorphism (SNP)-based markers need to be analyzed simultaneously. Here, we
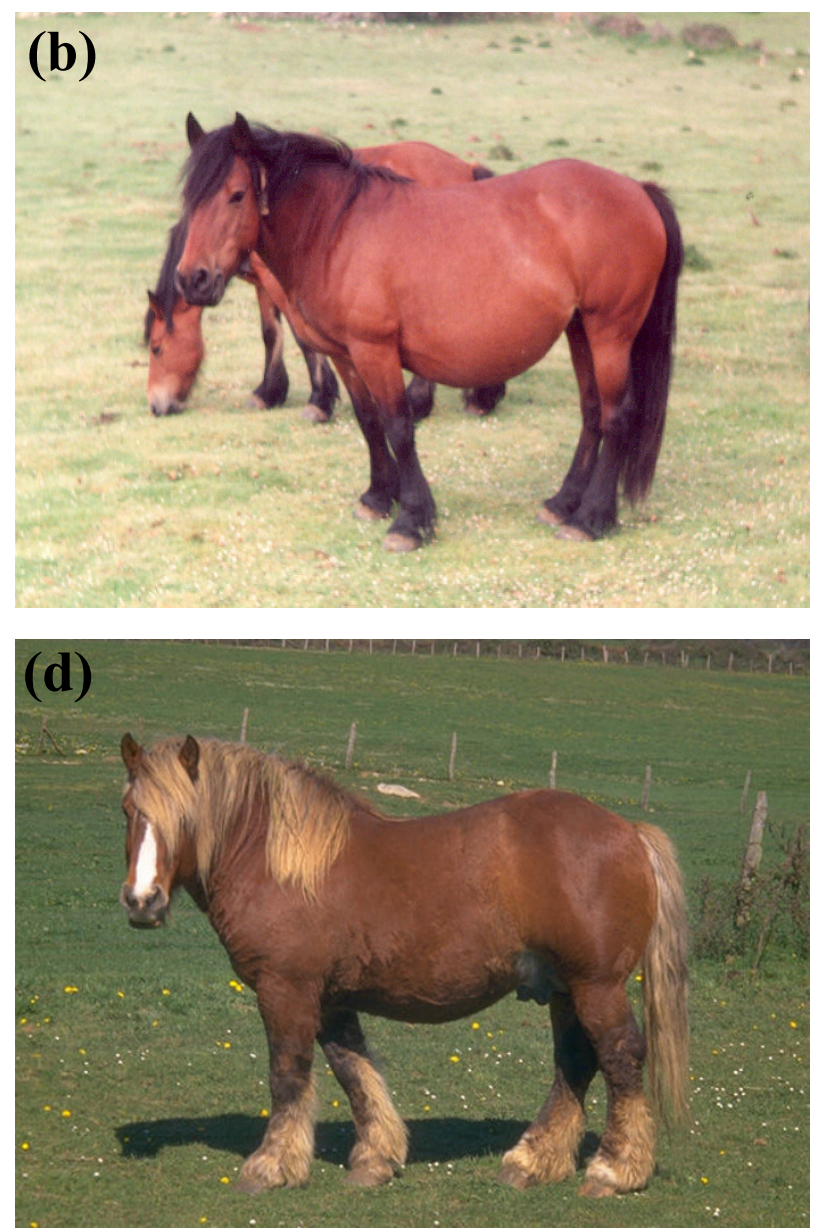

\section{Figure I}

The four native breeds analyzed. (a) Pottoka and (b) Jaca Navarra ponies; (c) Euskal Herriko Mendiko Zaldia and (d) Burguete heavy horse breeds. 
describe a fast, cost-effective and reliable alternative method for the routine genotyping of alleles causing chestnut coat color in horses based on SNaPshot ${ }^{\oplus}$. This SNP detection methodology involves few manipulation steps, all of which are susceptible to automation, and has scalable flexibility for low- and high-throughput capacity [9].

\section{Materials and methods}

125 Pottoka, 56 Jaca Navarra, 24 EHMZ and 44 Burguete purebred horses from the Western Pyrenees (northern Spain) were sampled, all of them included in their respective stud books (Figure 1). Genomic DNA was isolated from blood using a STARlet automatic robot (Hamilton) and DNeasy 96 Blood \& Tissue Kit (Qiagen). SNaPshot ${ }^{\circledast}$ performs an SNP genotyping assay based on a single-base extension method. First, a 154-bp fragment of MC1R exon 1 was amplified from genomic DNA using 5'-GCAACCT-
GCACTCACCCAT-3' (forward) and 5'-TTGTCCAGCTGCTGCAACA-3' (reverse) primers. All PCR reactions were carried out in $5 \mu \mathrm{l}$ volumes with 5-20 ng template DNA, $0.2 \mathrm{mM}$ dNTPs, $0.3 \mu \mathrm{M}$ of each primer and $1.0 \mathrm{U}$ of AmpliTaq Gold polymerase in the accessory Buffer II (Applied Biosystems) and with $1.5 \mathrm{mM} \mathrm{MgCl}_{2}$. A PCR program consisting of initial denaturation at $95^{\circ} \mathrm{C}$ for $10 \mathrm{~min}, 35$ cycles at $95^{\circ} \mathrm{C}$ for $20 \mathrm{~s}, 57^{\circ} \mathrm{C}$ for $20 \mathrm{~s}$, and $72^{\circ} \mathrm{C}$ for $30 \mathrm{~s}$, and a final extension at $72^{\circ} \mathrm{C}$ for $10 \mathrm{~min}$ was performed in a Veriti ${ }^{\mathrm{TM}}$ 96-Well Thermal Cycler (Applied Biosystems). All PCR products were cleaned up with $1.5 \mu \mathrm{l}$ of ExoSAP$\mathrm{IT}^{\circledast}$ (USB Corporation) at $37^{\circ} \mathrm{C}$ for $45 \mathrm{~min}$ and then incubated at $80^{\circ} \mathrm{C}$ for $15 \mathrm{~min}$. PCR products were then used to perform the specific SNaPshot ${ }^{\circledast}$ reaction containing C901T SNP-specific primer (5'-ATATTGCTGCCTGGCCGTGT-3') and G903A SNP-specific primer (5'ATATATTGCTCATGCTCACCAGCAGGT-3'). All SNaPshot $^{\circledast}$ reactions were carried out in a volume of $6 \mu \mathrm{l}$ which

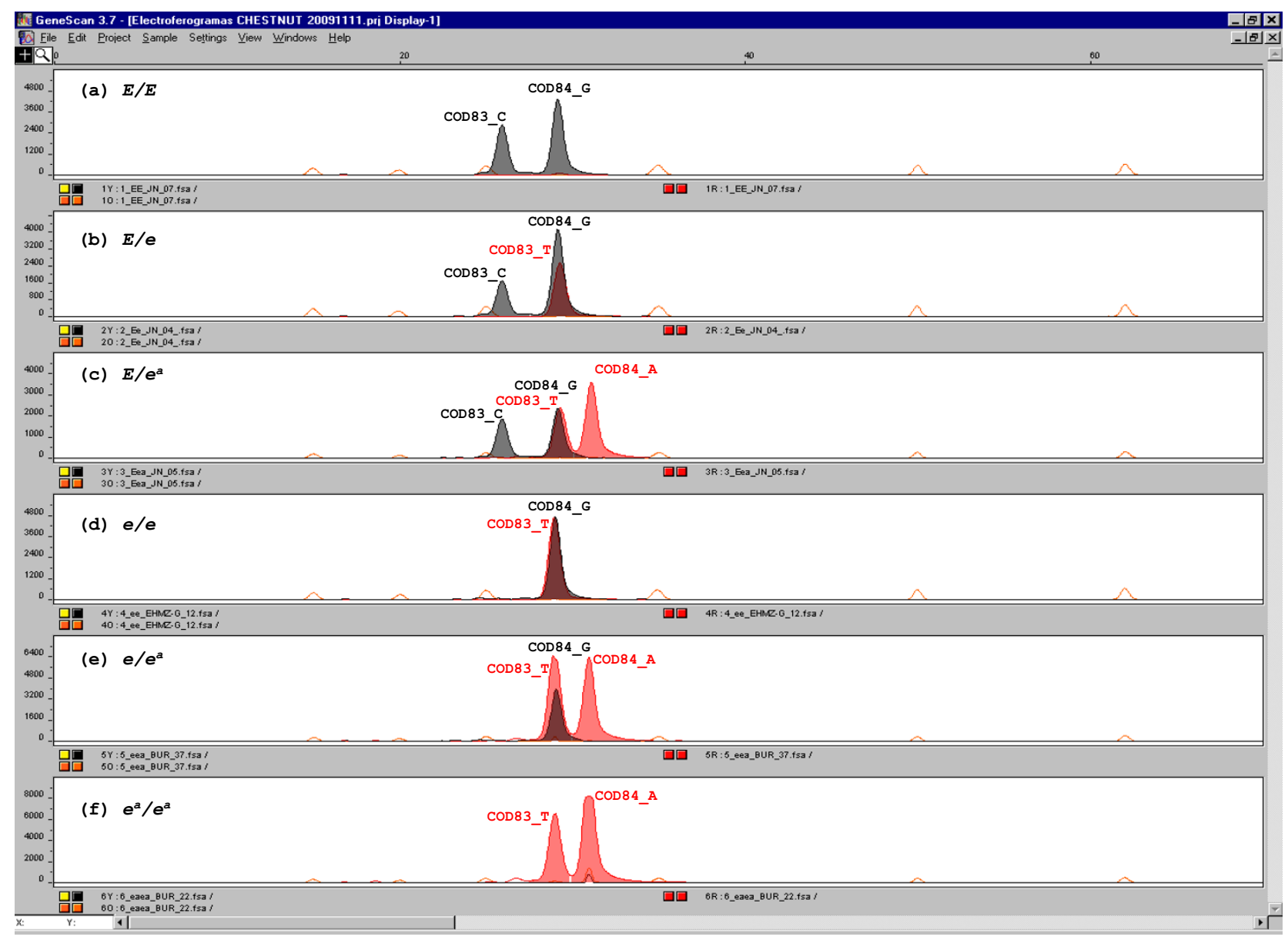

Figure 2

Electropherograms for the different genotypes. (a) $E / E$ (C/C; G/G), (b) $E / e(C / T ; G / G)$, (c) $E / e^{a}(C / T ; G / A)$, (d) e/e (TT; GG), (e) e/e $e^{a}(T T ; G A)$ and (f) $e^{a} / e^{a}(T T ; A A)$. 
Table I: Sample size $(\mathrm{N})$, genotypes and frequencies of the $E$, e and $\mathrm{e}^{a}$ alleles of the Extension gene and Hardy-Weinberg Equilibrium (HWE) test results for the Pottoka and Jaca Navarra ponies and for the Euskal Herriko Mendiko Zaldia (EHMZ) and Burguete heavyhorse breeds.

\begin{tabular}{|c|c|c|c|c|}
\hline Breed & Pottoka & Jaca Navarra & EHMZ & Burguete \\
\hline $\mathrm{N}$ & 125 & 56 & 24 & 44 \\
\hline \multicolumn{5}{|l|}{ Genotypes } \\
\hline$E / E$ & 86 & 20 & 2 & 4 \\
\hline$E / e$ & 38 & 34 & 11 & 17 \\
\hline$E / e^{a}$ & 1 & 2 & 4 & 0 \\
\hline e/e & 0 & 0 & 7 & 18 \\
\hline $\mathrm{e} / \mathrm{e}^{a}$ & 0 & 0 & 0 & 4 \\
\hline $\mathrm{e}^{a} / \mathrm{e}^{a}$ & 0 & 0 & 0 & I \\
\hline \multicolumn{5}{|l|}{ Allele frequencies } \\
\hline$E$ & $0.844 \pm 0.023$ & $0.679 \pm 0.044$ & $0.396 \pm 0.07 I$ & $0.284 \pm 0.048$ \\
\hline $\mathrm{e}$ & $0.152 \pm 0.023$ & $0.304 \pm 0.043$ & $0.521 \pm 0.072$ & $0.648 \pm 0.051$ \\
\hline $\mathrm{e}^{a}$ & $0.004 \pm 0.004$ & $0.018 \pm 0.013$ & $0.083 \pm 0.040$ & $0.068 \pm 0.027$ \\
\hline HWE $p$ value & $0.1347 \pm 0.0004$ & $0.0007 \pm 0.0000$ & $0.0739 \pm 0.0002$ & $0.1604 \pm 0.0002$ \\
\hline
\end{tabular}

included $1.8 \mu \mathrm{l}$ of cleaned up PCR products, $0.2 \mu \mathrm{M}$ of each specific primer and $0.85 \mu$ l of SNaPshot ${ }^{\circledR}$ reagents, with a program including an initial denaturation at $96^{\circ} \mathrm{C}$ for $1 \mathrm{~min}$ and 25 cycles consisting of $96^{\circ} \mathrm{C}$ for $10 \mathrm{~s}, 60^{\circ} \mathrm{C}$ for $35 \mathrm{~s}$, in the same thermal cycler used before. All SNaPshot $^{\circledast}$ specific products were cleaned up with $1 \mu$ of Shrimp Alkaline Phosphatase - SAP (Promega Biotech) at $37^{\circ} \mathrm{C}$ for $60 \mathrm{~min}$ and then incubated at $75^{\circ} \mathrm{C}$ for $15 \mathrm{~min}$. Finally, these SNaPshot ${ }^{\circledast}$ specific products were analyzed by capillary electrophoresis in a 3130xl Genetic Analyzer and with GeneMapper Software (Applied Biosystems) according to manufacturer's instructions. Hardy-Weinberg equilibrium (HWE) tests and Expected Heterozygosity $\left(\mathrm{H}_{e}\right)$ were calculated using GENEPOP software, version $4.0[10]$.

\section{Results and Discussion}

Electropherograms of the 249 analyzed samples exhibited the six different possible genotypes: $E / E, E / e, E / e^{a}, e / e, e / e^{a}$ and $e^{a} / e^{a}$ (Figure 2 ). A sequencing assay was carried out for at least two individuals of each genotype, except for the $e^{a} /$ $e^{a}$ genotype, for whom only one individual was identified, using the Big-Dye-Terminator v3.1 protocol (Applied Biosystems) in a 3130xl Genetic Analyzer, in order to validate the "chestnut coat-color" genotypes and verify that the electropherograms corresponded to the expected sequences. In all cases analyzed, the results obtained were successful. Genotypes and allele frequencies are shown in Table 1. Pottoka, EHMZ and Burguete samples are in HWE, whereas Jaca Navarra sample is not. This may be due to the deliberate exclusion practiced by Jaca Navarra breeders of chestnut individuals, who are not accepted in the stud book. For this reason, allele frequencies for this breed should be interpreted with caution.

The results obtained reveal two important findings: firstly, the $e^{a}$ mutation seems to be present in several Cantabrian
Coast horse breeds, since up to now, this mutation has only been reported to be present in the Asturcón pony breed [11]; secondly, the frequency of alleles causing chestnut coat color ( $e$ and $e^{a}$ ) is highly variable in these breeds, ranging from $f=0.156 \pm 0.023$ in Pottoka to $f=$ $0.716 \pm 0.048$ in Burguete. If we interpret these frequencies to be in part indicative of the degree of introgression of foreign genetic material into the breed, then the present results suggest an important degree of mixing in the pony breeds, especially in the Jaca Navarra breed. Since the aim of breeders of Cantabrian Coast ponies is to decrease the incidence of chestnut animals among these horses, these results underline the need for mating management which avoids reproductive animals who carry chestnut alleles; the DNA tools presented herein will be very useful for genotyping to this end. It should be stressed that if individuals who carry the $e$ and $e^{a}$ alleles are excluded from the reproductive processes of the Pottoka and Jaca Navarra breeds (genotypes for the Agouti-signaling peptide gene are also used in Jaca Navarra [12]), there would not be a significant reduction of genetic variability in either of the two breeds. An analysis of these samples using 17 microsatellites (unpublished results), showed that the expected heterozygosity of the Jaca Navarra population would change from $\mathrm{H}_{\mathrm{e}}=0.744(\mathrm{~N}=56)$ to $\mathrm{H}_{\mathrm{e}}=0.751\left(\mathrm{~N}_{E / E}=20\right)$, while in the case of Pottoka, this would change from $\mathrm{H}_{e}=$ $0.779(\mathrm{~N}=125)$ to $\mathrm{H}_{\mathrm{e}}=0.778\left(\mathrm{~N}_{E / E}=86\right)$.

The method described herein is a fast, cost-effective and reliable alternative for the routine genotyping of alleles causing chestnut coat color in horses. We estimate a cost per SNP and per individual of 1.59 Euro when analyzing two SNPs (excluding cost associated with DNA extraction). This cost could be further reduced to 0.42 Euro per SNP, per individual when 10 SNPs are analyzed, or to 0.21 Euro when 25 SNPs are analyzed simultaneously [9]. In contrast, the RT-PCR based method [8] involves a sim- 
ilar expense for two SNPs, but this cost would increase in a manner approximately proportionate to the number of analyzed SNPs (Applied Biosystems, pers. comm.). The $\mathrm{SNaPshot}{ }^{\circledast}$ methodology which we propose herein is fast insofar as it is a medium-throughput technology. Moreover, it presents the additional advantage that increasing the number of analyzed SNPs only slightly increases the total time necessary to obtain results.

\section{Conclusions}

In conclusion, we have developed and validated a SNaPshot $^{\circledast}$ based methodology for the robust, reliable and reproducible genotyping of chestnut coat color alleles in a fast, simple and cost-effective way. Furthermore, since SNaPshot ${ }^{\oplus}$ can analyze more than 10 SNPs at the same time [9], this is not a closed method but an open one, where more markers for multiple desired traits can be added allowing their simultaneous routine genotyping. Finally, this methodology, proven in this study to be useful for four Cantabrian Coast horse breeds, it is not exclusive to these horses breeds; rather it could be extended to any horse breed and, therefore, to any breeders association, which needs to know the 'chestnut coat color' associated genotype for a certain reproductive animal.

\section{Competing interests}

The authors declare that they have no competing interests.

\section{Authors' contributions}

FR performed all SNaPshot ${ }^{\circledast}$ methodology concerning analysis, DNA genotyping and sequencing, as well as drafted the manuscript. MI and CM participated in the design of the study as well as in manuscript writing and editing. AE conceived the study and was responsible for funding and supervising the research project. All authors approved the final manuscript.

\section{Acknowledgements}

The authors would like to thank Nerea Liaño and Igor Velado, staff of the research group, and Irati Miguel, from the Unit of Sequencing and Genotyping of the Genomic Service - Bizkaia (SGlker-UPV/EHU) for their technical assistance. We also thank Euskadiko Pottokaren Federazioa, Koldo Gotzon Pérez from Arabako Foru Aldundia, Jon Agirre from Sergal and Alberto Pérez de Muniain from ITG-Ganadero for their kind collaboration with the collecting of samples and for providing photos. This research was partially funded by grants from the Department of Agriculture and Fisheries of the Basque Government (PA 08/05).

\section{References}

I. Cañón J, Checa ML, Carleos C, Vega-Plá JL, Vallejo M, Dunner S: The genetic structure of Spanish Celtic Horse breeds inferred from microsatellite data. Anim Genet 2000, 3 I (I):39-48.

2. Morais J, Oom M, Malta-Vacas J, Luís C: Genetic structure of an endangered Portuguese semiferal pony breed, the Garrano. Biochem Genet 2005, 43:347-64.

3. Ludwig A, Pruvost M, Reissmann M, Benecke N, Brockmann GA, Castaños P, Cieslak M, Lippold S, Llorente L, Malaspinas AS, Slatkin M, Hofreiter M: Coat color variation at the beginning of horse domestication. Science 2009, 324:485.
4. Alonso de la Varga M: El Caballo Hispano-Bretón. Capitulo III. In Razas Equinas de Castilla y León Junta de Castilla y León, Consejería de Agricultura y Ganadería, Salamanca, Spain; 2000.

5. Searle AG: Comparative genetics of coat colour in mammals London: Logos Press; 1968.

6. Marklund L, Johansson-Moller M, Sandberg K, Andersson L: A missense mutation in the gene for melanocyte-stimulating hormone receptor $(M C I R)$ is associated with the chestnut coat color in horses. Mamm Genome 1996, 7:895-9.

7. Wagner HJ, Reissmann M: New polymorphism detected in the horse MCIR gene. Anim Genet 2000, 31 :289-90.

8. Royo LJ, Fernández I, Azor PJ, Álvarez I, Pérez-Pardal L, Goyache F. A novel method for routine genotyping of horse coat color gene polymorphisms. J Anim Sci 2008, 86: I29|-5.

9. Karniol B, Shirak A, Baruch E, Singrün C, Tal A, Cahana A, Kam M, Skalski Y, Brem G, Weller JI, Ron M, Seroussi E: Development of a 25-plex SNP assay for traceability in cattle. Anim Genet 2009, 40:353-6.

10. Rousset F: Genepop'007: a complete reimplementation of the Genepop software for Windows and Linux. Mol Ecol Resour 2007, 8: 103-106.

II. Royo LJ, Álvarez I, Pérez-Pardal L, Fernández I, Rincón C, Lorenzo L, Payeras L, Gutiérrez JP, Goyache F: Selección de reproductores basada en el genotipo del gen MCIR en las razas equinas Asturcón y Mallorquín. Proceedings of the 'XIII Jornadas sobre Producción Animal': I 2-I 3 May 2009; Zaragoza (Spain) 2009:I29-I30.

12. Fernández J, Azor PJ, Gómez MD, Royo LJ, Valera M: The genotype for coat colour genes as a criterion in the design of semen Banks in the Jaca Navarra breed. In Proceedings of the '59th Conference of the European Association for Animal Production (EAAP)': 24-27 August 2008; Vilnius (Lithuania) EAAP Publications; 2008:283-283.

\section{Publish with BioMed Central and every scientist can read your work free of charge}

"BioMed Central will be the most significant development for disseminating the results of biomedical research in our lifetime." Sir Paul Nurse, Cancer Research UK

Your research papers will be:

- available free of charge to the entire biomedical community

- peer reviewed and published immediately upon acceptance

- cited in PubMed and archived on PubMed Central

- yours - you keep the copyright

Submit your manuscript here:

http://www.biomedcentral.com/info/publishing_adv.asp
BioMedcentral 